\title{
A TRANSITIONING SABAH IN A CHANGING MALAYSIA
}

\section{Mohamad Nawab Mohamad Osman}

S. Rajaratnam School of International Studies, Nanyang Technological University, SINGAPORE

Email: ismnawab@ntu.edu.sg

Published online: 15 April 2017

To cite this article: Mohamad Nawab Mohamad Osman. 2017. A transitioning Sabah in a changing Malaysia. Kajian Malaysia 35(1): 23-40. https://doi.org/10.21315/km2017.35.1.2

To link to this article: https://doi.org/10.21315/km2017.35.1.2

\begin{abstract}
The East Malaysian state of Sabah has played an important political role in the ruling Barisan Nasional (BN) government. In the 2013 election, the component parties of $B N$ in the state delivered a substantial number of parliamentary seats and helped the BN hold the government, despite losing the national popular vote. This paper argues that the changing political dynamics in Sabah will not have a significant impact on the Malaysian political landscape. The paper will examine the socio-political history of Sabah and analyse the impact of this history on contemporary Sabah politics. Further, the paper will study recent political developments, such as the Lahad Datu incursion and the issue of illegal immigrants in Sabah, and how these developments will shape the political landscapes of both Sabah and the larger state. The paper concludes by drawing a trajectory of Sabah's politics. It is concluded that despite Sabah's growing political importance for the BN, the political developments in Sabah will not significantly alter the landscape of Malaysian politics and that Sabah as a state will remain marginal in the larger context of Malaysian politics.
\end{abstract}

Keywords: Sabah, 2013 elections, Malaysian politics

\section{INTRODUCTION}

The East Malaysian state of Sabah played a decisive but also perhaps underappreciated role in the last Malaysian general election. Although much attention has been devoted to Barisan Nasional's (BN) worst electoral performance in Malaysian history, it must not be forgotten that the BN managed to clinch the majority of parliamentary seats, in spite of losing the popular vote thanks to BN's electoral success in the East Malaysian states. In hotly contested 
elections, Sabah and Sarawak are known as a "fixed deposit" because they have provided the expected and substantial bulk of the parliamentary seats to secure the continued mandate of the BN government. The 2013 General Election was no exception, and Sabah delivered. Indeed, Sabah's continued importance can be attributed to the generally stable relationship between the state and federal governments over the past two decades, notwithstanding the occasional tensions between these entities. This paper makes the case that the changing political dynamics in Sabah, distinct as it is from West Malaysia, are not likely to bring about significant changes to the overall Malaysian political landscape. There are three parts to this paper. First, the paper seeks to analyse the socio-political history of Sabah, which continues to leave a lasting legacy for the state. Second, the paper examines the current political challenges within the state and its impact on the larger Malaysian political landscape. Last, the paper projects a trajectory for the future political development of Sabah, arguing that internal Sabah politics will probably not have a significant impact on the larger Malaysian political landscape. To appreciate these points better, an understanding of Sabah's modern history is crucial.

\section{A BRIEF SOCIO-POLITICAL HISTORY OF MODERN SABAH}

The history of modern Sabah can be traced to the 1880s when, after a series of political and diplomatic maneuverings (Ooi, 2004: 1164), a British commercial syndicate called British North Borneo Chartered Company assumed the administration of Sabah (Saunders, 2002: 88), then named North Borneo. This "company state" colonial arrangement for North Borneo, akin to the British East India Company rule over much of India in earlier times (Metcalf and Metcalf, 2006: 56), continued more or less uninterrupted for more than half a century, until the Japanese invasion and subsequent occupation of North Borneo in 1942.

After World War Two, when the Allied forces retained control over North Borneo, the latter was shortly made a formal British colony. Despite a brief history of revolts against the British North Borneo Chartered Company's rule in the 1890s (Buckley, 1968), the anti-colonial sentiments and yearning for independence in North Borneo between World War Two and the formation of Malaysia can generally be categorised as less than fervent (Lim, 2008: 40-43), at least compared to those in the neighbouring Sarawak. This observation was underscored by the report of the Cobbold Commission, which was tasked with determining the intention of the people of North Borneo as to the formation of Malaysia, of which Sabah would be a constituent part. This Commission found that one-third of the North Borneo people were in favour of creating Malaysia, one-third were against it, and the remaining one-third had a divided opinion (Cobbold Commission, 1962). Indeed, as the British Government was preparing North Borneo for self-rule and subsequent independence, efforts had to be made 
to inculcate political awareness and train an adequate number of competent administrators from amongst the people of North Borneo.

The multiracial demography of Sabah (Noor, 2013: 542) almost inevitably dictates that Sabah politics largely entails a delicate and occasionally precarious balance between the interests and aspirations of the various ethnic and religious communities in Sabah. Although these communities are varied and often intricate in their composition, with many ethnic subdivisions in the land's native population, they may generally be grouped into three main socio-political ethno-religious groups: the Muslim $^{1}$ bumiputeras $^{2}$, the non-Muslim bumiputeras $^{3}$, and the Chinese ${ }^{4}$ (Brown, 2010: 36-27). Although the two bumiputera ethno-religious groups often held sway over the political rule of Sabah, the Chinese traditionally played a crucial balancing role. For example, when there were 48 elected state assembly seats, Muslim and non-Muslim bumiputeras each held 18 seats and thus represented the majority of the voters, and the remaining 12 seats represented the Chinese majority.

Around the time of the formation of Malaysia (1963), two prominent political figures emerged: Tun Mustapha, representing the Muslim bumiputeras, became the governor, and Donald Stephens, ${ }^{5}$ heading the United Pasokmomogun Kadazan Organization (UPKO) and representing the non-Muslim bumiputeras, became the first chief minister of Sabah. Sabah, which practices a state version of parliamentary democracy, sees its chief minister, instead of its governor, as assuming the true political powers of the state. ${ }^{6}$ Political tussling ensued between the camps, with Tun Mustapha, by then heading United Sabah National Organization (USNO), becoming chief minister in 1967.

For nearly the next decade under Tun Mustapha, who was empowered with ordering detention without trial, Sabah experienced a somewhat authoritarian rule with coercive measures in favour of religious conversion to Islam (Lim, 2002: 48). It was also during this period that many southern Filipinos, fleeing civil war in their homeland, started to arrive and settle in Sabah in substantial numbers (Tirtosudarmo, 2007: 122). Indeed, this influx of Filipino migrants would lead to serious social and political repercussions in Malaysia decades later, as discussed below.

In the 1976 state election, Tun Fuad Stephens, helming the Berjaya party, toppled the USNO government. After Stephens' demise in an airplane tragedy, Sabah saw rapid developments for nearly a decade under his successor, Harris Salleh. During this time, however, the non-Muslim bumiputeras became increasingly disillusioned with what they perceived as the creeping hegemony of Muslim bumiputeras in Sabah politics, as exemplified by the increasing association of bumiputera with "Malayness" and Islam (Siddique and Suryadinata, 1982: 679). Although there were problems of economic mismanagement, such as huge investments in poorly conceived development projects, it was the cultural-ethnic policies that exposed the true weakness of the authoritarian Harris-led government (Means, 1991: 154-155). For instance, one 
of the most contentious integrationist policies implemented by Harris was the introduction of the term "pribumi" to classify non-Muslim bumiputeras in Sabah, which the Christian Kadazan-Dusun community perceived as a threat to eradicating their indigenous identity and relegating them to the status of "secondclass citizens" below the Malay-Muslim community (Zawawi, 2013: 305-306).

These dissatisfactions arising from Harris' one-sided policies culminated in Joseph Pairin Kitingan, the Huguan Siou or paramount leader of the KadazanDusun community, and his Parti Bersatu Sabah (PBS) winning the state election of 1985. Not initially blessed by the federal ruling coalition, BN, PBS subsequently joined $\mathrm{BN}$; however, they pulled out on the eve of the 1990 Malaysian general election and continued to rule Sabah until 1994.

Federal-state relations became increasingly tense during the PBS state administration. On the one hand, the "Sabah First" regional sentiments were riding a rising tide among Sabahans across communities, occasionally verging on calls for independence or at least self-rule. On the other hand, the West Malaysian-centric federal government, which has always been Muslimdominated, did not feel comfortable with a faraway state dominated by nonMuslim ruling politicians. The backbone party of $\mathrm{BN}$, the United Malays National Organization (UMNO), saw an opportunity to extend its reach to Sabah after USNO dissolved itself to make way. The development efforts in Sabah became the unintended victims of the federal-state tensions, with decrepit infrastructure and abandoned development projects dominating the landscape throughout the state (Jomo and Wee, 2003: 445-451).

Things came to a head in 1994, when several PBS assemblymen left the party and either joined UMNO or formed their own BN-friendly parties. The PBS state government collapsed as a result, and Sabah ushered in a BN "rotation" system that was introduced by the Mahathir administration and lasted for nearly a decade, whereby the chief minister is selected with the endorsement of the Head of State and his post is rotated biennially among the various state component parties of BN. Whereas the chief minister was meant to represent both Muslim and non-Muslim bumiputeras and Chinese communities for two years to ensure the unity and consolidation of all Sabahans, the resulting system led to charges of serious administrative and socio-economic lapses wrought with rampant governmental corruption, which had damaging political and economic consequences for Sabah (Mohd Jefri, 2012; Lim, 2002). Eventually, then-Prime Minister Abdullah Badawi announced that the rotation system with a constantly changing system made Sabah so impossible to govern that the system had to be scrapped (Malaysiakini, 2004). The rotation system was shelved in 2004, only after the current chief minister, Musa Aman, assumed the reins of government in 2003 and continued to rule until the present, which has ensured UMNO and, hence, federal dominance over Sabah for over a decade.

The key reasons for Musa's longevity in office can be attributed to his tactfulness in maintaining very positive ties with the federal government as one 
of his top political goals, coupled with strong support from other BN component parties in Sabah and his successful efforts to draw continued support from the populace (Puyok, 2013a: 227, 230-231, 236-237). Musa's tactic of building a good working relationships with the federal government stands in contrast to the often maverick posture of some of his predecessors, who sought to challenge the federal government, which often brought about a federal backlash that curtailed the political ambitions of Sabahan leaders. Musa's political astuteness at both the federal and state level has placated both potential unhappiness and challenges to his hold onto power.

The main lesson to be gleaned from Sabah's modern socio-political history lies in the often "invisible" but always ubiquitous "federal hand" in Sabah's affairs, playing one political camp against another, occasionally even across the supposedly rigid government/opposition divide (Tirtosudarmo, 2007: 122). Tun Fuad Stephens's call for Sabah's position within the federation to be reviewed was seen as sufficiently threatening to the Malaysian federal government. His resistance to Sabah being part of Malaysia led to him being sidelined in favour of his political arch nemesis, Tun Mustapha (Loh, 1992: 228230). Later, the federal government dealt harshly with Tun Mustapha when he threatened to lead Sabah in seceding from Malaysia. This threat, coupled with his refusal to sign oil concession agreements with the federal government, led Tun Mustapha to engineer Harris Salleh's withdrawal from USNO to form a new party, Berjaya. The state government led by Mustapha collapsed following massive defections from USNO to join Berjaya. This strategy was repeated nearly two decades later, when the unyielding PBS state government also collapsed when massive defections were contrived by the then-federal government. The state has since remained subordinate to the demands of the federal government.

Thus, this subordination under federal meddling is fundamentally aimed to neutralise the state government and its leaders from exhibiting independence in political ideals and goals for Sabah, particularly postures that steer Sabah away from federal dominance, and hands over the political leadership to non-Muslim politicians. Malaysia as a federation operates in a manner whereby constituent state governments have limited access to the federal state's power, revenue and resources, further emphasised by the hegemony of $\mathrm{BN}$ over politics since independence (Loh, 2010: 132-133). Currently, it is very unlikely and probably unthinkable for the UMNO-led BN state government in Sabah to openly and overtly challenge federal dominance, except for a drastic political change, such as an opposition takeover of the Sabah government in elections or the threat of secession. However, as mentioned above, the latter scenario is at most a remote possibility because past challenges to the federal government have been met with a strong response to both BN-led governments in Sabah and opposition-led governments elsewhere; an example of this can be seen in the immediate aftermath of the 2008 elections, where the federal government moved swiftly to 
cancel all memoranda of understanding between opposition state governments and the Ministry of Tourism (Loh, 2010: 134-135). Although the opposition under the banner of the Pakatan Rakyat (and now Pakatan Harapan) has made further significant inroads in Sabah, BN is unlikely to surrender Sabah due to its continued importance in delivering parliament seats. The recent events in the Sarawak state elections, which saw an overwhelming victory for BN, further emphasise two points: BN recognises the importance of East Malaysia for its political dominance, and the politics of the East differ dramatically from those of its Peninsula counterpart.

\section{SABAH FROM "FIXED DEPOSIT" TO SOMEWHAT UNSUNG KINGMAKER}

Although the Malaysian federal government had in the past viewed Sabah as a "troublemaker" politically, most notably because this state has voted for an essentially opposition PBS state government in four successive state elections in the 1980s and early 1990s, this perception has since shifted drastically. Since 1994, Sabah (not unlike Sarawak) has often also been hailed as a "fixed deposit" state for the BN for having consistently delivered the bulk of their parliamentary seats to the ruling coalition (The Economist, 2012). For nearly half a century, the federal ruling BN coalition enjoyed an almost insurmountable and overwhelming parliamentary majority. The seats delivered to the BN in Sabah (and Sarawak) have been a major factor for this continued support. Sabah was particularly crucial in securing BN's political position following the sacking of Anwar Ibrahim and the emergence of the Reformasi movement (Loh, 2003: 246-247). The swing of the Malay voters against the BN meant that the Malaysian government was at risk of losing the 1999 elections and would indeed have done so if not for Chinese and East Malaysian voters (Weiss, 2000: 418).

It was, however, the 2008 Malaysian General Election that sounded the alarms for the $\mathrm{BN}$. The BN's traditional comfortable reliance on securing the majority of seats in West Malaysia was questioned for the first time. The BN lost its much-vaunted two-third parliamentary majority ${ }^{7}$ for the first time and could have lost the government, if not for the East Malaysian seats. Indeed, of the total of 222 seats in the Malaysian parliament, 56 (or over 25\%) are demarcated in Sabah (25) and Sarawak (31), which has led some to label these states as "kingmakers" in future closely contested general elections (Oh, 2013: 1-3). The BN's potential loss of more predominantly non-bumiputera seats in West Malaysia would likely be counterbalanced by gains in predominantly bumiputera seats, yielding a net election result in West Malaysia similar to that of 2008 (where the BN only narrowly surpassed the opposition Pakatan Rakyat [PR] coalition). 
The 2013 Malaysian General Election was then often characterised as a potential "watershed" event, whereby the voters, many of whom were enfranchised for the first time, would realistically be able to decide whether to retain the ruling $\mathrm{BN}$ coalition that has been in power since the country achieved its independence or to opt for the opposition PR alliance that has been driving to take over the baton. The 2013 General Election results were, however, underwhelming and counter-climactic both federally and for Sabah. Federally, although they won the majority of popular votes and made further dents in BN's parliamentary majority, PR still failed to form the federal government (Chin, 2013: 538).

In Sabah, BN lost 2 (of 25) parliamentary and 10 (of 60) state seats to PR; although these results are mildly impressive, they fell well short of the anticipated (mainly parliamentary) "contribution" of Sabah toward a putative federal regime change. It should, however, be noted that after the 2013 General Election, with 133 seats in a 222-seat parliament, BN could not have formed its federal government without its 22 seats from Sabah. The BN state government was further buttressed when three PR assemblymen decided later in the same year to either join BN component party outright or declare themselves "BNfriendly" independents (Ding, 2011; Koon, 2012; Asmady and Suzalie, 2014).

It should therefore be emphasised that Sabah's gradual shifting from a fixed deposit state to a little-heralded kingmaker state for BN's continued federal rule is due less to a deliberate design of Sabah politicians than to the eroding nationwide electoral fortune of $\mathrm{BN}$.

\section{SABAH AS A RELUCTANT CHAMPION FOR STATE RIGHTS: OIL ROYALTIES AND THE CONTROVERSIAL IMMIGRANT ISSUE}

The more important parliamentary role played by Sabah parliamentarians has not escaped the attention and subsequent clamor of those who advocate enhanced "state rights" for Sabah from both the ruling and opposition coalitions. Indeed, Sabah (together with Sarawak) enjoys special rights distinct from other Malaysian states, such as state control over immigration and land matters, that are enshrined in the Malaysia Agreement (MA) (agreement relating to Malaysia, 2013) of 1963, when Malaya, Sabah, Sarawak and Singapore (exited in 1965) formed Malaysia as supposedly equal partners. The ties between the federal government and Sabah in particular were occasionally been strained in the initial decades after the formation of Malaysia, as each side maneuvered to take up more elbow room when tussling for rights and privileges in an unprecedented federation. However, because the Sabah state governments have almost always been formed by BN component parties (with the notable semi-exception of the second half of PBS era), contestations in federal-state relationships, as illustrated above, have almost always ended in favour of the federal side. 
The state rights or state sovereignty sentiments were reportedly on the rise in Sabah, even before the 2013 general elections. They are manifested mainly in two superficially hotly contested issues. One is the call for increasing the state's share of petroleum royalties above and beyond the current $5 \%$ to further fill up the state's coffers for development projects (Yeoh, 2014: 289-291). The petroleum royalty agreements between the federal government and the various petroleum-producing states (such as Sabah, Sarawak and Terengganu) were negotiated in the 1970s, when Malaysia ventured seriously into petroleum exploration and exploitation in its waters. Many in Sabah feel that an increase in royalties is called for to narrow the development gap between Sabah and West Malaysia (Chan, 2014). The Sarawak state assembly's passing of a bill to increase the share of royalties for that state to $20 \%$ only added fuel to the debate, although the federal government did not concede to the state (Davidson, 2015). Sabah's oil royalties look to remain at $5 \%$, polarising the locals, but opposition parties within Sabah continue to harp on the issue. Unlike Sarawak, where the strong character of Chief Minister Adenan Satem has leverage over the federal government, as demonstrated in the recent elections, and can thus make demands for more royalties, despite not receiving any, Sabah is not in a similar bargaining position. Discontent over this issue has existed for several years, but the Sabah BN politicians appear reluctant to address the issue. In particular, when juxtaposed against Sarawak, Sabah's relationship with the federal government seems to be subservient and unable to draw full benefits. Rather than demonstrating its importance to the $\mathrm{BN}$, it has emphasised its obsequious position within the federation for a number of reasons, as discussed below.

Another issue concerns the presence of mostly Filipino immigrants in Sabah. In addition to the abovementioned tens of thousands of southern Filipino refugees, it was alleged that both the USNO and Berjaya governments actively encouraged mostly Filipino Muslim migrants to enter and settle in Sabah to "dilute" the non-Muslim bumiputera composition of Sabah population and thereby cement the dominance of Muslim bumiputeras in Sabah politics and society. These efforts were allegedly intensified by the federal government during the PBS era, under covert programs such as "Project IC" or "Project M", which granted identity, residency and even nationality documents to Muslim Filipino migrants to enable them to vote in BN's favour (Zulaikha, 2013). The Sabah state government has also been strongly criticised for not taking any concrete actions to tackle this long-standing problem of illegal immigrants, and it has also been accused of milking votes from illegal immigrants over the past several decades (Free Malaysia Today, 28 August 2011).

It is interesting to note that at first glance, it would appear that only nonMuslim bumiputeras and the Chinese communities of Sabah would clamor for an investigation into putting a resolute end to these allegations of misdeeds, as the Muslim bumiputeras may be argued to exercise solidarity with their co-religious brethren. In reality, the deep concern for the presence of immigrants in Sabah is 
felt and voiced by all communities in Sabah (Zulaikha, 2013; New Sabah Times, n.d.).

The federal government finally heeded these calls for investigating the immigrants in Sabah and formed a Royal Commission of Inquiry (RCI) not long before the 2013 general election (The Borneo Post Online, 2 June 2012). However, these efforts came too late to help diffuse the public displeasure against immigrants. Voters in Sabah expressed their anger over this sensitive issue in the ballot box, and the indigenous community in Sabah, especially the Kadazan-Dusuns, reduced their support for the ruling BN during the 2013 elections (Kong, 2013; Puyok, 2013b).

After prolonged series of hearings (Vanar, 2013) and deliberations (The Malaysian Insider, 11 August 2012), the commission finally submitted its report to the federal government, which only recently released its content. Although conceding that Project IC might have existed, the commission concluded it was largely the work of corrupt officials, and no political party was found to be deliberately handing out citizenship to immigrants (Chi and Chan, 2014). The commission recommended that both a permanent committee and a working committee be set up to address the immigrant issues in Sabah (The Malay Mail, 3 December 2014).

Many in Sabah viewed the report as either disappointing or lackluster or at least failing to effectively tackle the issue (Goh, 2014). Joseph Pairin Kitingan $^{8}$, for example, initially hesitated to head the working committee recommended by the royal commission before finally accepting it (Vanar, 2014c). The real sentiments in Sabah on these immigrants may be argued to be more nuanced than they were perceived in the media. Some in the Sabah business community, for example, view them as indispensable human resources in Sabah's economy, particularly in the oil palm and services sectors. A long-term solution to the immigrants issue in Sabah would entail resolute determination and actions from both the federal and state governments in stopping their additional inflows and a transformation in the economic operations of the private sector in Sabah (Puyok, 2014; Liow, 2003; The Malaysian Insider, 4 December 2014).

\section{POLITICS AS USUAL: INTRIGUES ABOVE ALL}

Despite the often colorful and cacophonous interplay of political actors in Sabah, the "real" politics of Sabah remain firmly dominated by UMNO, particularly its internal maneuverings at both the federal and state levels. This may partially be attributed to three extra-UMNO factors. First, the main state opposition coalition, which is nominally PR but, in actuality, comprises various factions centred on political personalities such as the assembly opposition leader Lajim Okim, Wilfred Bamburing, and the maverick Jeffrey Kitingan, continues to be caught up with internal disagreements about their dominance over one another and has yet 
to be able to capitalise on Sabahans' supposedly changed sentiments for political gains above and beyond occasional insignificant sloganeering. In any case, it will not come as any surprise to ordinary Sabahans if elected representatives from any side choose to cross to the winning side for reasons only known to themselves, as noted above.

Second, it would appear that a cloud of debilitating malaise is shrouding the non-Muslim bumiputera component parties of BN in Sabah. Over the years, and especially since the collapse of the PBS government in 1994, they have witnessed both the demographic ${ }^{9}$ and electoral ${ }^{10}$ declines of their community relative to the Muslim bumiputera community. The prohibition of using the word "Allah" to signify the Christian God, albeit only in a Catholic publication to date, and the creeping ban on publishing the Bible in the Malay language have added to the worries about the viability of the non-Muslim bumiputera community. However, these fears and frustrations were not effectively channeled into urgent calls for actions by credible community leaders, who remained helpless in the face of these onslaughts and thus continue to toe the UMNOdominated BN line. Split in at least three different BN component parties, including PBS, UPKO and Parti Bersatu Rakyat Sabah (PBRS), they have their hands full with trying to outdo each other in gaining the favour of their UMNO colleagues and convincing their constituents of their continued relevance in representing the interests and voices of their communities. Further, Bernard Dompok, the UPKO leader, decided to quit politics last year (Vanar, 2014a). All of these presented a dilemma to the average non-Muslim bumiputera voters, who see hardly any credible BN leader among their community but cannot grasp at a presentable leadership figure from the opposition (Chin, 2014: 118-124).

Third, the Chinese community, which used to play a crucial role in balancing the political interests of all communities, also appeared to be debilitated. In 2013, most Sabah Chinese voters cast their lot with the opposition, in tandem with the voting trends of most Malaysian Chinese voters. Although most urban Chinese majority seats were yielded to the opposition coalition as a result, a number of $\mathrm{BN}$ Chinese politicians managed to retain their non-Chinese majority seats. These latter were similarly split into at least four BN component parties, including Liberal Democratic Party (LDP), Gerakan, Malaysian Chinese Association (MCA) and PBS, and looked primarily toward UMNO for political guidance and appreciation, which the average Chinese voters unfortunately perceived negatively. The vocal Chinese opposition figures, in contrast, have yet to attain mature political status. Thus, for both the non-Muslim bumiputera and the Chinese communities in Sabah, charismatic leaders, perhaps in the line of a younger Joseph Pairin Kitingan, have yet to emerge to rally their respective communities and better their lots (Puyok, 2013b).

Sabah UMNO politics are overshadowed by the longstanding feuds between the camps of Musa Aman, the incumbent chief minister, and Shafie Apdal, the UMNO national vice president and a former federal minister. Musa 
undoubtedly wants very much to consolidate and prolong his rule of the state. The Shafie camp, in contrast, works hard to present their leader as a suitable substitution for Musa. Incessant political bickering between the camps became the order of the day in Sabah politics, with, for example, groups of Sabah UMNO divisional leaders declaring ${ }^{11}$ their allegiance to one camp or another. The focus of political maneuverings in Sabah thus trains on survival tactics, with largesse and privileges alternating as carrots and sticks for political loyalty. Shafie's dismissal from the federal cabinet in July 2015 ameliorated this contest somewhat, but he remains a potent political force to reckon with, given his influence within UMNO Sabah. His recent quitting of UMNO is likely to divide UMNO in Sabah and could weaken the party's hold on certain areas of East Sabah, where Shafie continues to wield substantial support. The Sabah Chief Minister, Musa Aman, who has led Sabah BN to three election victories (at both the federal and state levels), has his own clever ways of preserving state rights and privileges, but many political matters ultimately must still be referred to the federal level. The political dynamic in Sabah is such that political and often ideological delineation among parties or coalitions is not as marked or rigid as it is in West Malaysia or even Sarawak. The crossing of party lines by elected representatives, for example, is both frequent and commonplace in Sabah and seemingly does not tarnish the reputation or electability of the perpetrator at all.

The implications of these dynamics on federal politics can be seen in several ways. First, the reputation or electability of the perpetrator may not be as important as the personality issues in regard to garnering votes in elections. Party-hopping and switching allegiances have been repeated in several occasions not only in Sabah but also in peninsular Malaysia, although it is not as frequent and rampant in the latter as it is in the former. The second implication, which flows from the first, is that the fluid nature of party loyalties implies that no single party, including the ruling government and the opposition, can afford to rest on its laurels. If the state government in Sabah chooses to challenge the status quo of subordination to the federal government, it is almost certain that the federal government would unleash its divide-and-conquer strategy of exploiting shifting party loyalties and personality-driven politics to weaken or strengthen political figures. Furthermore, there is no guarantee that opposition political inroads by the PR in the last general election are durable because this coalition may have to contend with similar party-hopping and allegiance switching dynamics, all of which could weaken the solidarity and coherence of the opposition coalition in Sabah politics.

There is of course no objective requirement that Sabah being a de facto kingmaker for federal politics should require it to proactively exercise a such role. However, such an opportunity may not present itself repeatedly, and if Sabah thus fully exerts itself to shrewdly advance its state interests, it may find that the scale of federal-state relations tips more in its favour. 


\section{CONCLUSION}

To conclude, the changing political dynamics in Sabah are not likely to have a major impact on the overall Malaysian political landscape. The prospects of Sabah returning to the rule of non-Muslim bumiputera political parties and leaders have become less worrisome to the federal government since the collapse of the opposition-led government in 1994 due to federal machinations and the turbulent nature of local Sabah politics. The successive BN, and hence, UMNOled governance of Sabah has helped quell the overtly pro-Sabah sentiments and subdue it in favour of federal interests. Indeed, Sabah shifted from being a thorn in the side of the federal government to become a prized asset in terms of securing crucial parliamentary votes to buttress the BN government's political dominance and victories in general elections. However, BN's political dominance in Sabah has not been made any easier, especially with the ongoing and heightened contentions over the issue of oil royalties and illegal immigrants. The Sulu claims, its ancillaries, intrusions and kidnappings are not just purely maritime and security issues (Inquirer.net, 2013). ${ }^{12}$ They are linked to the existing problem of illegal immigrants in Sabah, and it inevitably casts doubt on the state and federal authorities' ability to tackle these issues. In spite of these problems, the political power in Sabah still rests firmly in the hand of the UMNO-led BN government, due to the complex interplay of internal bickering, politicking, a lack of credible leadership, and personality politics.

Although no observers seriously doubt that most parliamentary seats in Sabah will return to the BN in future elections, changes in the popular sentiments and a heightened awareness of popular rights could translate into more "swing" seats in Sabah, where a slim voting majority could move to either side of the political divide. It remains to be seen whether this swing phenomenon will impact federal-state relations. Ultimately, however, the federal-state relationship concerning Sabah is unlikely to be strongly affected one way or the other in the near future because the state winner will still have to work with the federal authorities for development needs in the state. Sabah shall remain a key insurance for the political dominance of the $\mathrm{BN}$, which will continue to pay the premium in this vital state of East Malaysia.

\section{NOTES}

1. Mainly Bajaus, Suluks and Brunei Malays and others.

2. The umbrella term used in Malaysia for indigenous peoples.

3. Mainly Kadazan-Dusun-Muruts, who are mostly Christians.

4. Mainly Hakkas, Hokkiens, Teochews and Cantonese.

5. Later Tun Fuad Stephens after conversion to Islam. 
6. Malaysia follows the federal political structure, where the 13 Malaysian state governments have jurisdiction in certain areas of governance. A 20point agreement was drawn up by leaders of North Borneo (Sabah), proposing terms for its incorporation into the new federation as the State of Sabah, which differs from the Federation agreement that governs the states in Peninsula Malaysia. These agreements include the commitment to ensure that the modification or withdrawal of any special safeguard granted to North Borneo by the central government must first be supported by the state government and that matters related to immigration will come under the jurisdiction of the state government.

7. Required to pass constitutional amendments, including one to change the number of parliamentary seats.

8. Joseph Kitingan brought PBS to rejoin BN and is now Sabah's Deputy Chief Minister.

9. In terms of percentage in population.

10. In terms of the number of parliamentary and state assembly seats with non-Muslim majority of voters.

11. Usually to the prime minister, who is also UMNO president.

12. In 2013, more than 200 armed militants arrived in Lahad Datu, Sabah from Southern Philippines. The group, calling themselves the "Royal Security Forces of the Sultanate of Sulu and North Borneo" represented Jamalul Kiram III, who was one of the claimants to the throne of the Sultanate of Sulu. Kiram stated that he sought to assert territorial control over Eastern Sabah. The Malaysian security forces attacked and routed the Sulu militants. At the end of the standoff, approximately 56 militants were killed, as were 6 civilians and 10 Malaysian security forces.

\section{REFERENCES}

Agreement relating to Malaysia between United Kingdom of Great Britain and Northern Ireland, Federation of Malaya, North Borneo, Sarawak and Singapore. 1963. United Nations Treaty Registered No. 10760.

Asmady Idris and Suzalie Mohamad. 2014. The continuing dominance of Barisan Nasional in Sabah. Kajian Malaysia 32(Supp. 2): 171-206.

Brown, G. 2010. Legible pluralism: The politics of ethnic and religious identification in Malaysia. Ethnopolitics 9(1): 31-52. https://doi.org/ 10.1080/17449050903557401.

Buckley, C. 1968. A school history of Sabah. London: Macmillan \& Co. 
Campbell, C. 2013. Sabah standoff: Diplomatic drama after Filipino militants storm Malaysia. TIME. 26 February. http://world.time.com/2013/02/26/ sabah-standoff-diplomatic-drama-after-sulu-militants-storm-malaysia/.

Chan, J. 2014. Doubtful oil royalty payouts will increase in Budget 2015. Sabah BN, Pakatan reps say. The Malay Mail Online. 9 October. $\mathrm{http} / /$ www.themalaymailonline.com/malaysia/article/doubtful-oil-royalty -payouts-will-increase-in-budget-2015-sabah-bn-pakatan.

Chi, M. and J. Chan. 2014. Corrupt officials' blamed for Sabah problems, but RCI says hands tied. The Malay Mail Online. 3 December. http://www.themalaymailonline.com/malaysia/article/corrupt-officialsblamed-for-sabah-problems-but-rci-says-hands-tied.

Chin, J. 2014. Second-class Bumiputera? The taming of the Dayak and Kadazandusun of East Malaysia. In Misplaced democracy: Malaysian politics and people, ed. S. Lemière, 109-128. Selangor, Malaysia: Strategic Information and Research Development Centre. - 2013. So close and yet so far: Strategies in the 13th Malaysian elections. The Round Table 102(6): 533-540. https://doi.org/10.1080/00358533. 2013.857145.

Cobbold Commission. 1962. Report of the Commission of Enquiry, North Borneo and Sarawak. Kuala Lumpur: Government Press.

Dangin, A. 2014. Illegal immigrants are ESSCom's biggest challenge. The Borneo Post Online. 24 June. http://www.theborneopost.com/2014/06/24/ illegal-immigrants-are-esscoms-biggest-challenge/.

Davidson, D. 2015. Dr M should stay out of Sarawak oil, gas royalty talks, says DAP. The Malaysian Insider. 29 January. http://www .themalaysianinsider.com/malaysia/article/dr-m-should-stay-out-ofsarawak-oil-gas-royalty-talks-says-dap.

Ding Jo-Ann. 2011. Remembering the Perak crisis. The Nut Graph. 10 January. $\mathrm{http}: / / \mathrm{www}$.thenutgraph.com/remembering-the-perak-crisis/.

Emirates 24/7. 2013. Pom Pom Island: Tourist killed, wife kidnapped. 16 November. http://www.emirates247.com/news/pom-pom-islandtourist-killed-wife-kidnapped-2013-11-16-1.528227.

Free Malaysia Today. 2011. Illegal immigrants in Sabah: A numbers game. 28 August. http://www.freemalaysiatoday.com/category/nation/2011/08/ 28/illegal-immigrants-in-sabah-a-numbers-game/ (accessed 15 April 2015).

Goh, M. 2014. Malaysia inquiry on Sabah illegal migrants fails on solutions. Channel News Asia. 3 December. http://www.channelnewsasia.com/ news/asiapacific/malaysia-inquiry-on-sabah/1508428.html.

Grudgings, S. and Hamzah, Al-Zaquan Amer. 2013. Malaysia coalition extends rule despite worst electoral showing. Reuters. 5 May. http://www. reuters.com/article/2013/05/05/us-malaysia-election-idUSBRE9430B72 0130505 . 
Inquirer.net. 2013. Sulu Sultan won't budge. 17 February. https://globalnation .inquirer.net/64715/sulu-sultan-wont-budge.

Jomo, K. S. and C. H. Wee. 2003. The political economy of Malaysian federalism: Economic development, public policy and conflict containment. Journal of International Development 15: 441-456. https://doi.org/10.1002/jid.995.

Kementarian Pertahanan Malaysia (KEMENTAH). 2010. Dasar pertahanan negara. Kuala Lumpur: KEMENTAH.

Kong, L. 2013. Sabah, Sarawak remain BN bastions. The Straits Times. 9 May. http://www.straitstimes.com/the-big-story/asia-report/malaysia-elections/ news/story/sabah-sarawak-remain-bn-bastions-20130509.

Koon, Y. Y. 2012. Learning from the Perak constitutional crisis. Malaysiakini. 2 October. http://www.malaysiakini.com/letters/210556.

Lim, K. S. 2002. DAP calls for a Commission of Inquiry whether Sabah has the worst problem of corruption in the country despite the 1994 Barisan Nasional 'Sabah Baru' election pledge of zero-corruption by 2,000 and whether this is because of the rotation system producing seven Chief Ministers in eight years. Media Conference Statement delivered on 10 October 2002. http://www.limkitsiang.com/archive/2002/oct02/lks 1888.htm.

Lim, R. 2008. Federal-state relations in Sabah, Malaysia: The Berjaya administration, 1976-1985. Singapore: Institute of South East Asian Studies.

Liow, J. C. Y. 2003. Malaysia's illegal Indonesian migrant labour problem: In search of solutions. Contemporary South East Asia 25(1): 44-64. https://doi.org/10.1355/CS25-1C.

Loh, F. K. W. 2010. Restructuring federal-state relations in Malaysia: From centralised to co-operative federalism? The Round Table, Routledge 99(407): 131-140. https://doi.org/10.1080/00358531003656180. . 2003. Electoral politics in Sabah, 1999: Gerrymandering, "Phantoms", and the 3Ms. In New politics in Malaysia, eds. F. K. W. Loh and J. Saravanamuttu, 228-252. Singapore: Institute of South East Asian Studies.

. 1992. Modernisation, cultural revival and counter-hegemony: The Kadazans of Sabah in the 1980s. In Fragmented vision: Culture and politics in contemporary Malaysia, eds. J. S. Khan and F. K. W. Loh, 225-253. North Sydney: Allen \& Unwin.

Lua, C. H. 2014. Esscom must beef up defence of Sabah's coast. Malaysiakini. 7 May. http://www.malaysiakini.com/letters/262105.

Malaysiakini. 2004. Rotation system for Sabah CM scrapped. 27 March. http://www.malaysiakini.com/news/19327 (accessed 20 July 2015).

Means, G. P. 1991. Malaysian politics: The second generation. Singapore: Oxford University Press. 
Metcalf, B. D. and T. R. Metcalf. 2006. A concise history of modern India. New York: Cambridge University Press. https://doi.org/10.1017/ CBO9781139207805.

Mohd Jefri Radius. 2012. Bringing back rotation will bankrupt Sabah - again. Daily Express. 24 November. http://www.dailyexpress.com.my/ read.cfm?NewsID $=1058$.

Mullen, J. 2013. Filipino group on Borneo claims to represent sultanate, Malaysia says. CNN. 15 February. http://edition.cnn.com/2013/02/15/world/ asia/malaysia-philippines-standoff.

New Sabah Times. n.d. Shut Kinarut refugee camp, says Rosnah. http://borneotoday004.blogspot.sg/2008/05/thursday-15-may-2008-closedown-refugee.html.

Noor, F. A. 2013. The 13th Malaysian general elections from a Sabah perspective. The Round Table Routledge 102(6): 541-548. https://doi.org/10. 1080/00358533.2013.857144.

Official Gazette of the Republic of the Philippines. 1968. 1878 Grant of Lease by the Sultan of Sulu to Britain: Profession Conklin Translation vis-à-vis Maxwell and Gibson Translation. 1 December. http://www.gov.ph/19 68/12/01/1878-grant-of-lease-by-the-sultan-of-sulu-to-britain-professionconklin-translation-vis-a-vis-maxwell-and-gibson-translation/.

Oh, E. S. 2013. From fixed deposits to kingmakers: Elections, East Malaysia and federal-state relations. RSIS Commentaries, 9 April, No. 057/2013: 1-3.

Ooi, K. G., ed. 2004. Southeast Asia: A historical encyclopedia, from Angkor Wat to East Timor. Santa Barbara, CA: ABC-CLIO.

Oxford Business Group. 2011. The report: Sabah 2011. Oxford: Oxford Business Group.

Puyok, A. 2014. RCI findings: Work towards a solution and stop finger pointing. The Malay Mail Online. 10 December. http://www.themalaymailonline .com/what-you-think/article/rci-findings-work-towards-a-solution-andstop-finger-pointing-arnold-puyok. . 2013a. Sabah's rise to national prominence and deepening UMNO dominance. In Awakening: The Abdullah Badawi years in Malaysia, eds. B. Welsh and J. U. H. Chin, 226-238. Petaling Jaya: Strategic Information and Research Development Centre.

2013b. The 'Rakyat Tsunami' in Sabah. New Mandala. 11 May. http://asiapacific.anu.edu.au/newmandala/2013/05/11/the-rakyattsunami-in-sabah/

Saunders, G. E. 2002. History of Brunei. London: Routledge Curzon.

Siddique, S. and L. Suryadinata. 1982. Bumiputra and pribumi: Economic nationalism (indiginism) in Malaysia and Indonesia. Pacific Affairs 54(4): 662-687. https://doi.org/10.2307/2757890. 
The Borneo Post Online. 2014. Kunak abduction proves steps ineffective - MP. 18 June. http://www.theborneopost.com/2014/06/18/kunak-abductionproves-steps-ineffective-mp/.

. 2012. Najib announces setting up of RCI to probe issue of illegal immigrants in Sabah. 2 June. http://www.theborneopost.com/ 2012/06/02/ najib-announces-setting-up-of-rci-to-probe-issue-of-illegalimmigrants-in-sabah-new/.

The Economist. 2013. Malaysia's election: A dangerous result. 11 May. http://www.economist.com/news/leaders/21577390-after-tainted-election -victory-najib-razak-needs-show-his-reformist-mettle-dangerous

2012. Cracking open the fixed deposits. 9 June. http://www.economist.com/node/21556617.

The Malay Mail. 2014. RCI moots 'permanent secretariat' to oversee all Sabah immigrant issues. 3 December. http://www.themalaymailonline.com /malaysia/article/rci-moots-permanent-secretariat-to-oversee-all-sabahimmigrant-issues.

The Malaysian Insider. 2014. Let's tackle Sabah illegal immigrants problem together, state BN tells Pakatan. 4 December. http://www.themalaysianinsider.com/malaysia/article/lets-tackle-sabahillegal-immigrants-problem-together-state-bn-tells-pakatan (accessed 20 July 2015).

. 2012. IC-for-votes claim focus of Sabah RCI. 11 August. http://www.themalaysianinsider.com/malaysia/article/ic-for-votes-claimfocus-of-sabah-rci/(accessed 20 July 2015).

The Star. 2014. Security forces foil Sabah intrusion bid. 7 February. http://www.thestar.com.my/News/Nation/2014/02/07/Security-forces-foil -Sabah-intrusion-bid.

. 2013a. Lahad Datu: Malaysian security forces in all out attack against Sulu gunmen. 5 March. http://thestar.com.my/news/story.asp?file=/ 2013/3/5/nation/20130305073854\&sec=nation. . 2013b. Lahad Datu: Sabah CPO - No halt to Ops Daulat until Sulu terrorists are flushed out. 30 March. http://www.thestar. com.my/News/Nation/2013/03/30/Lahad-Datu-Sabah-CPO--No-halt-toOps-Daulat-until-Sulu-terrorists-are-flushed-out/.

Tirtosudarmo, R. 2007. Mencari Indonesia: Demografi-politik pasca-Soeharto (in Indonesian). Jakarta: Lembaga Ilmu Pengetahuan Indonesia.

Vanar, M. 2014a. Bernard Dompok to announce resignation as UPKO president on Wednesday. The Star. 3 March. http://www.thestar.com.my/News/ Nation/2014/03/03/Dompok-to-announce-resignation-as-Upko-presidenton-Wednesday/.

. 2014b. Two abducted from resort off Semporna. The Star. 3 April. http://www.thestar.com.my/News/Nation/2014/04/03/Sempornakidnapping-Semporna/ (accessed 15 January 2015). 
. 2014c. Pairin accepts post on illegals panel. The Star. 27 December. http://www.thestar.com.my/News/Nation/2014/12/27/Pairin-accepts-poston-illegals-panel-Its-a-proactive-move-towards-resolving-migrantproblem-in-Sa/.

. 2013. RCI on Sabah immigrant issue begins public hearings from Monday. The Star. 11 January. http://www.thestar.com.my/News/Nation/ 2013/01/11/RCI-on-Sabah-immigrant-issue-begins-public-hearings-fromMonday/.

Weiss, M. 2000. The 1999 Malaysian general elections: Issues, insults, and irregularities. Asian Survey 40(3): 413-435. https://doi.org/10. $2307 / 3021154$.

Yeoh, T. 2014. Responsible resource management of the oil and gas sector in Malaysia: Issues, challenges, and opportunities. In Misplaced democracy: Malaysian politics and people, ed. S. Lemière, 283-312. Selangor, Malaysia: Strategic Information and Research Development Centre.

Zawawi Ibrahim. 2013. The new economic policy and the identity question of the indigenous peoples of Sabah and Sarawak. In The new economic policy in Malaysia: Affirmative action, ethnic inequalities and social justice, eds. E. T. Gomez and J. Saravanamuttu, 293-316. Singapore: NUS Press \& ISEAS; Petaling Jaya: Strategic Information and Research Development Centre.

Zulaikha Zulkifli. 2013. I processed thousands of ICs for Sabah illegals. Malaysiakini. 28 February. http://www.malaysiakini.com/news/222557. 